\title{
„PYSZNE” TŁUMACZENIE, CZYLI JAK UCZYĆ PRZEKŁADU PRZEPISÓW KULINARNYCH Z JĘZYKA ANGIELSKIEGO NA JĘZYK POLSKI
}

\section{Wstęp}

W dydaktyce przekładu niezwykle istotnym aspektem pozostaje właściwy dobór tekstów i najodpowiedniejszej metody. Bez wątpienia odnosi się to w szczególności do pierwszej styczności studentów kierunków neofilologicznych z przedmiotem, jakim jest translatoryka, innymi słowy - do ich niejednokrotnie pierwszej przygody z tłumaczeniami. Refleksja nad takim stanem rzeczy wydaje się niezwykle słuszna i ważna z wielu powodów. Przede wszystkim nie ulega wątpliwości, że celem nauczyciela przekładu, który ma zamiar wprowadzić młodych adeptów sztuki tłumaczenia w świat translatoryki, jest ich zachęcenie i zmotywowanie do samodzielnego zgłębiania w przyszłości wszelkich niuansów i problemów związanych z procesem przekładowym. Istotne jest bowiem, by podczas pierwszych zajęć nie zniechęcić studentów i nie przerazić ogromem pracy, którą należy wykonać, aby opanować nie- 
zbędny w tych czynnościach warsztat translatorski. W związku z tym słuszne wydaje się, by na tych początkowych zajęciach zaproponować studentom takie teksty, które z jednej strony będą tekstami nieskomplikowanymi zarówno w kwestiach merytorycznych, jak i lingwistycznych, a z drugiej - odpowiadać będą obecnemu zapotrzebowaniu na nie na współczesnym rynku usług tłumaczeniowych.

Wydaje się zatem, że wymogi te spełniają w dużym stopniu przepisy kulinarne. Nie są to wprawdzie teksty proste (choć na pozór wielu studentów w taki sposób je odbiera), a niektóre z nich sprawiają ogromne trudności tłumaczeniowe, ale ogólnie rzecz biorąc, z uwagi na to, że stanowią one niejako część wspólnego wszystkim ludziom doświadczenia (każdy przecież ma do czynienia z produktami spożywczymi, ich jedzeniem, gotowaniem czy przyrządzaniem potraw), są łatwiejsze w kontekście rozumienia tekstu wyjściowego i rozwiązywania poszczególnych problemów leksykalnych wynikłych w trakcie wykonywania przekładu. Ponadto wydaje się, że przepisy kulinarne należą do tego rodzaju tekstów, na które panuje dość wysokie zapotrzebowanie na współczesnym rynku usług tłumaczeniowych. Nie ulega wątpliwości, że ostatnimi czasy zapanowała na świecie swoista moda na gotowanie. Oprócz wielu programów telewizyjnych czy blogów poświęconych tematowi gotowania pojawiło się również mnóstwo nowych książek kucharskich oraz literatury pięknej z komponentem kulinarnym $\mathrm{w}$ tle, najczęściej tłumaczonych z języków europejskich ${ }^{1}$, czy też poradników zdrowotnych, w których jedna część poświęcona jest przepisom kulinarnym. I nie ma się czemu dziwić - przecież kuchnia i gotowanie to serce każdego domu, to część ludzkiej codzienności i egzystencji. Nie widać, by zapotrzebowanie na tego typu pozycje spadało (na rynku wydawniczym zwłaszcza anglojęzyczne pozycje dotyczące kulinariów i zdrowego żywienia zyskują coraz większą popularność), słuszne wydaje się $\mathrm{w}$ takim razie włączenie do sylabusu z przedmiotu translatoryka zajęć związanych z tłumaczeniem bardziej praktycznych tekstów, tu: przepisów kulinarnych.

Istotną kwestią pozostaje jednak w tym wypadku dobór metody uczenia przekładu. W niniejszym artykule nacisk położony zostanie na podejście skierowane na proces czynności tłumaczenia (analiza poszczególnych etapów przekładu oraz potencjalnych błędów w jego tworzeniu), a nie na gotowy produkt (kiedy studenci przynoszą zadane wcześniej tłumaczenie i na podstawie

1 Na szczególną uwagę zasługują tu m.in. takie tytuły jak Kuchnia z Zielonego Wzgórza. Przepisy L.M. Montgomery autorstwa K. Crawford i E. Crawford (Warszawa 2007), Moje życie we Francji J. Child (Warszawa 2010) czy Kuchnia Franceski P. Pezzellego (Warszawa 2010). 
przygotowanych tłumaczeń analizuje się już popełnione błędy). Podejście zorientowane na proces wydaje się wskazane szczególnie na wczesnym etapie zgłębiania sztuki przekładu, i to z wielu względów. Gile (2009: 14-15) podaje wiele korzyści stosowania tego podejścia w dydaktyce translatorycznej. Przede wszystkim istnieje większe prawdopodobieństwo stosowania przez studentów strategii i technik omawianych przez nauczyciela na bieżąco, niż wtedy, gdy analiza bazuje na tekście powstałym - nie da się ukryć - metodą prób i błędów. Ponadto nauczyciel, który skupia się na procesie tworzenia tłumaczenia, a nie na gotowym produkcie, ma szansę wykazania się większą elastycznością i nie musi tracić czasu na pokazywanie studentom ich błędów, a dzięki temu nie ryzykuje zniechęceniem młodych adeptów sztuki tłumaczenia do wykonywania pracy tłumacza w przyszłości. Nauczyciel ma wtedy także większą pewność, że studenci zastosują omawiane metody i strategie translatorskie, niż gdyby mieli sami przystępować do tłumaczenia zadanego tekstu w domu.

Jeśli ponadto przyjąć, że właściwy dobór tekstów na zajęcia z tłumaczeń polega na tym, by teksty te analizowano niejako w całości, a nie tylko fragmentarycznie (przy czym do przetłumaczenia można wybrać tylko krótsze wycinki całego tekstu) i były one jednocześnie autentyczne i zgodne ze współczesną rzeczywistością oraz obecnym na nie zapotrzebowaniem (Preložniková, Toft 2004: 90-91), to przepisy kulinarne wydają się doskonale odpowiadać tym wymogom.

Niniejszy artykuł ma zatem na celu analizę przepisów kulinarnych jako specyficznego rodzaju tekstu w pełni nadającego się do włączenia go do sylabusów z przedmiotów translatorycznych, zwłaszcza na wczesnych etapach nauki przekładu; przyjrzenie się najpowszechniejszym problemom $\mathrm{w}$ ich tłumaczeniu, biorąc pod uwagę aspekty językowe oraz kulturowe; a także ukazanie krok po kroku, jak można wykorzystać przykładowy przepis kulinarny $\mathrm{w}$ dydaktycznym podejściu translatorskim nastawionym na proces.

\section{Przepis kulinarny jako rodzaj tekstu użytkowego}

Nie ulega wątpliwości, że teksty użytkowe są tekstami, które cechuje niejednolitość i wewnętrzne zróżnicowanie. Mają one jednak ze sobą dużo wspólnego: są to przede wszystkim teksty praktyczne, przekazujące określone informacje. Ich celem jest nakłonienie odbiorcy do podjęcia określonych działań, np. przyrządzenia jakiegoś dania. Współcześnie są to teksty, które z uwagi na 
fakt, że przynależą do form wykorzystywanych w komunikacji międzynarodowej, stają się coraz bardziej popularne na rynku tłumaczeniowym oraz na zajęciach z translatoryki (Mocarz 2007: 133).

Przepisy kulinarne i - ogólnie biorąc - książki kucharskie należą do specyficznego rodzaju tekstów. Pozornie wydaje się bowiem, że z uwagi na ich treść są to teksty wchodzące do kategorii gatunków empirycznych/deskryptywnych. Jednak nawet te książki kucharskie, które sprawiają wrażenie teksów rzeczowych, wręcz fachowych, rzadko kiedy pisane są za pomocą technicznego czy naukowego stylu (Hervey, Higgins, Haywood 1995: 164).

Należy zgodzić się z Piotrowską (2011: 39), podkreślającą fakt, że przepisy kulinarne jedynie pozornie stanowią teksty informacyjne, w których przeważa znaczenie denotacyjne, gdyż oprócz informowania i instruowania bardzo często przekonują do podjęcia pewnych działań, wywołują określone reakcje i emocje, wyrażają nastawienie autora itp. Nie ulega wątpliwości, że przepisy kulinarne mają na celu nakłonienie czytelnika do wykonania konkretnych czynności, których konkretnym, finalnym produktem jest gotowe danie. Stąd też nadmierny nacisk jedynie na stronę denotacyjną takiego tekstu może spowodować pewne jego zaburzenia nie tylko w trakcie tłumaczenia, ale również podczas procesu jego recepcji.

Nie da się ukryć, że przepisy kulinarne to typowe teksty-hybrydy. Ogromną trudność sprawia próba zaklasyfikowania ich do konkretnego rodzaju czy gatunku, przede wszystkim dlatego, że pełnią one wielorakie funkcje. Nie ulega wątpliwości, że jedną z nich jest funkcja informacyjna: przepisy przekazują bowiem informacje dotyczące sposobu przyrządzenia określenia potrawy, a niekiedy także - w słowach wstępnych do danego przepisu - informują o historii dania, jego walorach odżywczych czy smakowych oraz zastosowaniu. Jednak oprócz tego omawiane teksty pełnią funkcję ekspresywną. Uwidacznia się ona przede wszystkim w użytych przez autora środkach stylistycznych (zdrobnieniach, słowach nacechowanych emocjonalnie, zdaniach wykrzyknikowych itp.). Przepisy kulinarne pełnią ponadto funkcję impresywną (instrukcje nakłaniające odbiorcę do podjęcia konkretnych działań), a niekiedy nawet - choć $\mathrm{z}$ tą spotykamy się dosyć rzadko - poetycką. Przepisy kulinarne niejednokrotnie pełnią także funkcję typowo komercyjną: zachęcają do kupna określonego produktu, przyborów kuchennych czy kuchennego sprzętu. Wielorakość wymienionych funkcji wpływa na pojawianie się trudności tłumaczeniowych takich tekstów, zwłaszcza w wyborze strategii dotyczącej odpowiedniego stylu i rejestru językowego, jakimi ma cechować się tekst docelowy. 


\section{Najczęstsze problemy i błędy tłumaczeniowe w przepisach kulinarnych}

Przepisy kulinarne - jak już stwierdzono na początku niniejszego artykułu mimo że pozornie sprawiają wrażenie tekstów dość prostych i zrozumiałych, powodują wiele problemów natury translacyjnej, a co za tym idzie, niosą ze sobą ryzyko popełnienia pewnych błędów w tłumaczeniu, zarówno na poziomie językowym, jak i pozajęzykowym. Na wstępie jednak warto odpowiedzieć na pytanie, czym w istocie są owe błędy tłumaczeniowe. Kozłowska (2001: 139-140), dzieląc błędy spotykane w przekładach na językowe i tłumaczeniowe, te drugie określa jako występujące tylko w tłumaczeniach, polegające na niewłaściwym wyrażeniu informacji i treści zawartych w tekście wyjściowym. Wskazuje również na przyczynę powstawania tego typu błędów. Otóż pojawiają się one w wyniku niewłaściwego zrozumienia bądź też całkowitego niezrozumienia tekstu oryginału, braku wiedzy specjalistycznej czy kulturowej, a niekiedy też pośpiechu w działaniu, niestaranności, nieuwagi, niedostatecznej koncentracji na określonych problemach leksykalnych. Błędy te wynikają z opisanych niżej problemów natury translacyjnej. Na zajęciach z translatoryki, poświęconych tłumaczeniu przepisów kulinarnych, warto poświęcić trochę czasu na refleksję nad problemami, które rodzi przekład tekstów związanych z gotowaniem. Dyskusja taka z pewnością dałaby studentom możliwość krytycznego podejścia do analizy tekstu wyjściowego, bez której - jak się zdaje - nie jest możliwe poprawne przetłumaczenie żadnego tekstu.

Problemy tłumaczeniowe w przypadku przepisów kulinarnych mają złożoną naturę i wynikają z wielorakich różnic zaznaczających się w tekstach angielskich i polskich. Różnice te uwidaczniają się przede wszystkim w sferze kulturowej. Problemy zaczynają się niekiedy już od samej nazwy potrawy. O ile nazwy typu „Pumpkin-Honey Soup” czy „Celery Kidney Cleanse” nie powinny sprawiać większych trudności - są to bowiem nazwy dość uniwersalne, które bez trudu można przełożyć na język polski bez utraty walorów treści w tekście oryginalnym - to już nie lada wyzwaniem staje się tłumaczenie takich oto przykładowych dań: „Toad-in-the-Hole”, „Roly-Poly” czy „Ploughman's Lunch”. Nazwy te sprawiają młodym tłumaczom niemałe problemy, ponieważ odnoszą się one do typowych dań brytyjskich, mających związek z brytyjską kulturą. Kwestią dyskusyjną zatem pozostaje podjęcie decyzji dotyczącej tego, czy nazwę taką przetłumaczyć na język polski, czy też lepiej zostawić ją w brzmieniu oryginalnym, a w przypisie zamieścić informację wyjaśniającą, czym w istocie dana potrawa jest i jakie są jej powiązania z kul- 
turą danego obszaru językowego. Skłaniać by się raczej należało ku tej drugiej opcji (zostawianiu nazwy w brzmieniu oryginalnym). Czy bowiem tłumaczenie nazwy „Toad-in-the-Hole” jako „kiełbaski zapiekane w cieście” nie spowodowałoby utraty pewnych walorów zawartych w oryginalnym brzmieniu, na dodatek rymowanym? Rozwiązaniem byłoby w tym przypadku, być może, znalezienie polskiego rymu, oddającego swoisty beztroski wydźwięk nazwy oryginalnej. Sytuacja przedstawia się podobnie z nazwą „Roly-Poly”. Pod względem denotacyjnym oznacza ona "roladę nadziewaną konfiturami”. $\mathrm{W}$ tłumaczeniu tym brak jednak - podobnie jak w poprzednim przykładzie - wspomnianej już beztroski, elementu lekkości, a przede wszystkim rymu. Trzecia nazwa - „Ploughman’s Lunch” - również stwarza problemy natury translacyjnej. Pod względem denotacyjnym jest to posiłek serwowany często w pubach angielskich, składający się z chleba, sera i marynowanych warzyw, jednakże w tłumaczeniu należałoby poszukać takiej nazwy, która po pierwsze byłaby zachęcająca do wypróbowania przepisu, a po drugie byłaby ekwiwalentna pod względem konotacyjnym. Przykładowym tłumaczeniem, niejako adaptacją, jest „śniadanie rolnika”. Wprawdzie pod względem denotacyjnym występują tu dość spore rozbieżności, jednak wydaje się, że nazwa polska może przynajmniej do pewnego stopnia wywoływać podobne skojarzenia co nazwa „Ploughman's Lunch”. Z tym też wiąże się częsty błąd tłumaczeniowy popełniany przez młodych adeptów sztuki przekładu - tego typu uwarunkowane kulturowo nazwy dań tłumaczą oni tak, by zachować jedynie warstwę denotacyjną wyrażenia, nie zwracając uwagi na jej aspekt konotacyjny. Aby uniknąć takiego błędu, warto zatem posłużyć się albo techniką adaptacyjną, zachowując przede wszystkim ekwiwalencję konotacyjną (co jednak nie zawsze okazuje się właściwe, zwłaszcza gdy tłumaczymy tekst, którego celem jest podkreślenie pewnych cech kulturowych danej kuchni), albo zostawić tekst w oryginalnym brzmieniu i zamieścić informację dotyczącą określonej potrawy.

Kolejnym problemem tłumaczeniowym, pojawiającym się zwykle tuż pod nazwą przepisu kulinarnego, czyli na liście składników, są miary kuchenne. Miary te najczęściej (wyjątkiem są tu na przykład dzieła literatury pięknej czy tłumaczenia przysięgłe) przelicza się tak, by odbiorca tłumaczenia nie miał trudności z właściwym przyrządzeniem danej potrawy, a przepis był czytelny, zrozumiały i można go było wykorzystać. I tu jednak pojawiają się pewne problemy, których młody adept sztuki przekład może nie być świadomy, a które mogą zaważyć na jakości dokonanego przez niego tłumaczenia. Chodzi przede wszystkim o różnice w jednostkach imperialnych systemu angielskiego i amerykańskiego. O ile np. brytyjska kwarta (ang. UK quart) 
równa się 40 uncjom w płynie (ang. UK fluid ounces), to już w systemie amerykańskim kwarta wyniesie 32 uncje (ang. US fluid ounces). Nie ulega wątpliwości, że odpowiednie przeliczenie danej miary ma niebagatelny wpływ na jakość gotowego tłumaczenia i późniejsze jego praktyczne zastosowanie.

Podobnie sytuacja przedstawia się w przypadku przyborów kuchennych. Przykładowo słowo pan może oznaczać rondelek, garnuszek, a nawet misę, w amerykańskim angielskim dodatkowo - formę do pieczenia. Świadomość młodego tłumacza $\mathrm{w}$ zakresie takich różnic na poziomie leksykalnym jest niezwykle istotna, przekłada się ona bowiem na jakość końcowego produktu procesu tłumaczenia. Podobnie sytuacja przedstawia się w kwestii niektórych jednostek kuchennych. Przykładowo: nierzadko w tłumaczeniach książek kucharskich z języka angielskiego na język polski spotyka się w liście składników wyraz filiżanka, który jest tłumaczeniem angielskiej miary cup. Najodpowiedniejszym tłumaczeniem jest w tym przypadku polskie słowo szklanka.

Niemałe trudności powodują także czasowniki wykorzystywane w części instruktażowej przepisu, np. sauté i fry. Oba czasowniki oznaczają proces smażenia, jednak po przeanalizowaniu dokładnych ich definicji widać różnice znaczeniowe pomiędzy nimi. Otóż według słownika Merriam-Webster ${ }^{2}$ czasownik sauté oznacza: „to fry in a small amount of fat", fry zaś - „to cook in a pan or on a griddle over heat especially with the use of fat". A zatem pierwsza $\mathrm{z}$ wymienionych czynności polega na smażeniu czegoś $\mathrm{w}$ niewielkiej ilości tłuszczu, ta druga zaś - na smażeniu w rondelku czy też na specjalnym rodzaju patelni ${ }^{3}$, tyle że $\mathrm{w}$ tym przypadku potrawę przygotowuje się właśnie z większą ilością tłuszczu niż w pierwszym z omawianych przypadków. Sauté można by zatem przetłumaczyć jako przysmażyć bądź, posługując się techniką opisową, jako krótko podsmażyć, używając niewielkiej ilości tłuszczu; fry natomiast po prostu jako usmażyć bądź smażyć.

O podobnych problemach tłumaczeniowych związanych $\mathrm{z}$ doborem właściwego ekwiwalentu pisze Piotrowska (2011: 43). Podaje ona następujące przykłady słów sprawiających problemy tłumaczeniowe: salami, które w języku polskim może odnosić się zarówno do żółtego sera, jak i suchej, wędzonej

2 http://www.merriam-webster.com/ (dostęp: 25 lipca 2012 r.).

3 Swoją drogą tłumaczenie przyboru kuchennego, jakim jest angielskie griddle, również stwarza trudności. Może być to bowiem specjalny rodzaj patelni (w języku polskim często spotykaną nazwą jest patelnia do naleśników), okrągła blacha czy też forma do pieczenia, a nawet elektryczny grill. Rozwiązaniem byłoby tutaj także pozostawienie słowa oryginalnego i dodanie do niego polskiego słowa objaśniającego, na przykład patelnia "griddle” bądź ruszt "griddle”. Ostateczny wybór zależy od rodzaju przepisu oraz potrawy, która ma zostać przygotowana na jego podstawie. 
kiełbasy; feta, które do niedawna nie miało polskiego odpowiednika ze względu na to, że ser ten nie był kiedyś tak popularny jak dziś; czy czasowników combine, whisk, toss, stir, które w języku polskim są trudne do jednoznacznego odróżnienia i znalezienia właściwych ekwiwalentów. Piotrowska przywołuje tu również kwestię tłumaczenia wyrażenia $1 /{ }_{8}$ teaspoon pepper, które także stanowi problem tłumaczeniowy prowadzący niekiedy do podejmowania przez niedoświadczonych tłumaczy nie do końca trafnych decyzji. W tym przypadku bardzo często spotyka się niemal mechaniczne tłumaczenie, które w języku polskim brzmi ${ }^{1}{ }_{8}$ tyżeczki pieprzu. Jest to oczywiście tłumaczenie poprawne, jednak w kontekście konwencji polskich przepisów kulinarnych właściwsze wyrażeniem wydaje się po prostu szczypta pieprzu - chodzi bowiem o niewielką ilość tej przyprawy.

Problemy tłumaczeniowe $\mathrm{w}$ przypadku przepisów kulinarnych mają ścisły związek z kwestiami stylu i rejestru językowego. Nie wszystkie przepisy są bowiem tekstami ściśle informacyjnymi - niektóre z nich (zwłaszcza w literaturze pięknej czy poradnikach o zdrowiu) charakteryzują się tzw. kwiecistym stylem, bogactwem środków stylistycznych, złożoną składnią itp. Właściwa diagnoza stylistyczna tekstu wyjściowego determinuje przyszłe wybory i strategie translatorskie, m.in. dobór stylu i rejestru językowego tekstu docelowego.

Wiąże się z tym także istotna kwestia relacji autora tekstu i czytelnika oraz forma zwracania się do adresata przepisu kulinarnego. Język angielski, $\mathrm{w}$ porównaniu $\mathrm{z}$ językiem polskim, nie daje $\mathrm{w}$ tym zakresie zbyt wielu możliwości (występuje tu przede wszystkim zaimek you). Należy zgodzić się z Belczykiem (2007: 35), który stwierdza, że automatyczne tłumaczenie zaimka you jako ty to jedno z "największych nieporozumień leksykalnych”. Argumentuje to tym, że po pierwsze you nie określa liczby (a zatem przetłumaczyć ten zaimek można również jako $w y$ ), a po drugie wcale nie oznacza, że autor tekstu zrezygnował z dystansu dzielącego go z czytelnikiem i w ten sposób chce się z nim spoufalić. Młody adept sztuki tłumaczenia zabierający się do przekładu przepisu kulinarnego niejednokrotnie popełnia w tym momencie błąd i tłumaczy automatycznie poszczególne zdania rozkazujące w formie instrukcji dotyczącej przygotowania danej potrawy (heat, mix, blanch). Słusznie radzi Belczyk (2007: 37), by nie tłumaczyć automatycznie i nie przenosić trybu rozkazującego do przekładu, a zastanowić się nad tym, co w takiej sytuacji powiedziałby polski autor, tu: polski autor książki kucharskiej. Warto w tym miejscu kierować uwagę studentów na teksty paralelne, w których niekiedy występuje bezpośredni zwrot do adresata (you tłumaczone jako ty bądź $w y$ ), ale częściej mamy do czynienia z konstrukcją bezokolicznikową (np. obrać, 
osuszyć, zmieszać) czy stworzeniem się kategorii my pomiędzy autorem przepisu a jego odbiorcą (smażymy, kroimy, odlewamy).

Nie są to oczywiście wszystkie problemy tłumaczeniowe, z jakimi można się zetknąć w tłumaczeniu przepisów kulinarnych, z pewnością jednak stanowią one dobry punkt wyjścia do dyskusji na temat przekładu tekstów związanych z gotowaniem. Elementy takiej dyskusji powinny zostać obowiązkowo włączone do zajęć, których temat dotyczyłby przekładu przepisów.

\section{Analiza przypadku - tłumaczenie przepisu kulinarnego na zajęciach z translatoryki}

Biorąc pod uwagę, że dydaktyka przekładu jest w Polsce dziedziną jeszcze stosunkowo słabo rozwiniętą, wyraźnie brakuje praktycznego podejścia do zajęć poświęconych tłumaczeniom pisemnym, zwłaszcza tekstów użytkowych. Pisząc o praktycznym podejściu do translatoryki, mam na myśli wypracowanie pewnych konkretnych metod nauczania tłumaczenia, $\mathrm{w}$ tym także refleksję nad określonymi ćwiczeniami, których celem ma być zmotywowanie studentów do samodzielnego zgłębiania wiedzy dotyczącej sztuki przekładu oraz rozwinięcie u nich umiejętności dokonywania przekładu tekstów, na które panuje obecnie dość duże zapotrzebowanie na rynku usług tłumaczeniowych.

Poniżej znajduje się swoisty konspekt na zajęcia $\mathrm{z}$ translatoryki, który można wykorzystać w nauczaniu tłumaczenia przepisów kulinarnych bądź innych tekstów ściśle związanych z kulinariami. Przyjmując, że na uczelniach wyższych ćwiczenia z danego przedmiotu trwają na ogół 90 minut, poszczególne elementy zajęć rozpisano z uwzględnieniem tego czasu.

Temat: Tłumaczenie przepisu kulinarnego

Cele:

- rozwinięcie umiejętności studentów w zakresie tłumaczenia tekstu użytkowego, którym jest przepis kulinarny,

- rozwinięcie umiejętności studentów w zakresie krytycznej analizy tekstu wyjściowego i dopasowywania pod jego kątem odpowiednich strategii translatorskich,

- rozwinięcie umiejętności korzystania z tekstów paralelnych.

Wstęp: Zajęcia te skupiają się głównie na wypracowaniu pewnej strategii translatorskiej związanej z tłumaczeniem przepisów kulinarnych, a także wyrobieniu umiejętności właściwego korzystania z tekstów paralelnych. 


\section{Procedura:}

Rozgrzewka:

- Nauczyciel przedstawia temat zajęć i określa zaplanowane zadania do wykonania. Wprowadza studentów w temat tłumaczeń przepisów kulinarnych, dokonując krótkiej analizy aktualnego zapotrzebowania na tłumaczenia ze sfery kulinariów na rynku tłumaczeniowym, tym samym motywując studentów do skoncentrowania się na zajęciach oraz podkreślając sensowność przeprowadzania zajęć tłumaczeniowych z zakresu tekstów użytkowych poświęconych gotowaniu - 2-3 minuty.

- Próba zdefiniowania przez studentów wyrażenia „przepis kulinarny” (praca w parach) - 2-3 minuty.

- Ćwiczenie na skojarzenia. Nauczyciel prosi studentów o podanie jak największej liczby polskich asocjacji związanych z wyrażeniem „przepis kulinarny". Ćwiczenie to ma na celu przypomnienie leksyki dotyczącej kulinariów, co następnie okaże się dużym ułatwieniem w czasie dokonywania przekładu z języka angielskiego na język polski - 2 minuty.

Ćwiczenia wprowadzające do właściwego tłumaczenia:

- Porównywanie treści polskich i angielskich przepisów kulinarnych przyniesionych przez studentów bądź nauczyciela (praca w grupach 3-4-osobowych) - 4 minuty.

- Porównywanie treści polskich i angielskich przepisów kulinarnych - dyskusja podsumowująca, angażująca wszystkich studentów. Oto przykładowe pytania, które może zadawać nauczyciel. Pytania te zaczerpnięto $\mathrm{z}$ książki Learning Translation Learning the Impossible? A Course of Translation from English into Polish (Piotrowska 2011: 40-41):

1) Jakie normy (konwencje) można wyróżnić, porównując format przepisów w językach polskim i angielskim?

2) W jaki sposób zaczynają się przepisy?

3) Jakie elementy tworzą ich strukturę? W jakiej kolejności owe elementy występują?

4) Czy przepisy zostały wzbogacone o zdjęcia, rysunki? Jeśli tak, jak wyglądają? Co przedstawiają?

5) Czy między przepisami kulinarnymi w języku polskim i angielskim występują różnice w odniesieniu do tytułów, zdań wprowadzających, listy składników, metody, sugestii dotyczących podawania potrawy, informacji o wartościach odżywczych, kaloriach, czasu przygotowania itp.? 
6) Czy na podstawie porównywanych przepisów można zauważyć jakiekolwiek różnice kulturowe?

Dyskusja powinna trwać około 7-10 minut.

Przystąpienie do wykonania procesu tłumaczenia:

- Nauczyciel rozdaje każdemu ze studentów przygotowany wcześniej przepis kulinarny, który ma zostać przetłumaczony w trakcie zajęć. Oto sugerowany przepis (Broadhurst 2000: 58):

Honey-Glazed Vegetables

Eating carrots and peas together is usually a bore, however with this recipe you'll want to have them all the time. The carrots, a source of vitamins $\mathrm{A}$ and $\mathrm{E}$, along with the vitamin $\mathrm{C}$ in the orange juice, will fully satisfy your body's need for antioxidant vitamins.

2 cups $(500 \mathrm{ml})$ carrots, sliced

1 cup $(250 \mathrm{ml})$ vegetable stock or water

1 cup $(250 \mathrm{ml})$ fresh peas

$1 / 4$ cup $(60 \mathrm{ml})$ orange rind

$1 / 2$ cup $(125 \mathrm{ml})$ orange juice

3 tbsp unpasteurized honey

2 tbsp butter

fresh rosemary, for garnish

Cook carrots in vegetable stock for 5 minutes or until liquid is reduced by two-thirds. Add peas and cook for 3 minutes. Add orange rind and juice, honey and butter; cook for 3 to 5 minutes longer.

Place vegetables on plates, garnish with rosemary and serve. This dish is delightful on its own or served with rice or roasted potatoes.

Serves 2.

- Studenci zapoznają się z tekstem - 3 minuty.

- Nauczyciel wyjaśnia ze studentami wszelkie niezrozumiałe wyrazy i wyrażenia - 3 minuty.

- Nauczyciel przeprowadza ze studentami dyskusję dotyczącą przepisu kulinarnego, z którym się zapoznali. Oto sugerowane pytania, które może zadać nauczyciel:

1) W jakim stylu napisano ten przepis kulinarny?

2) Jaki jest cel tekstu?

3) Czy zdania są złożone, czy proste?

4) Jaki jest rejestr językowy tego tekstu? 
Dyskusja powinna potrwać około 5 minut.

- Nauczyciel rozdaje studentom przepis na podobną potrawę w języku polskim i zwraca uwagę na korzyści płynące z wykorzystywania tekstów paralelnych podczas procesu tłumaczenia. Studenci porównują oba teksty (praca w parach, a następnie wspólne omówienie różnic i podobieństw) - 7 minut. Poniżej znajduje się sugerowany tekst do porównania ${ }^{4}$ :

Marchew glazurowana w miodzie

Składniki:

6 średnich marchewek

2 czubate łyżki masła

3 łyżki miodu

2 łyżki soku z pomarańczy

$1 / 4$ łyżeczki soli

szczypta imbiru

szczypta cynamonu

Wykonanie:

1. Umyte i obrane marchewki kroimy w cienkie, skośne plastry.

2. W garnuszku o grubym dnie roztapiamy na wolnym ogniu masło. Dodajemy miód, sok pomarańczowy, sól, imbir oraz cynamon.

3. Dodajemy marchewki, mieszamy tak, aby pokryły się sosem.

4. Garnuszek przykrywamy i gotujemy do czasu, aż sos wyparuje, a marchewki zmięknął (25-35 minut).

5. W połowie gotowania marchewki należy przemieszać. Pod koniec, gdy sos się prawie całkowicie zredukuje, mieszamy już częściej.

- Nauczyciel wraz ze studentami zastanawia się nad głównymi trudnościami tłumaczeniowymi obecnymi w tekście (m.in. tytuł przepisu, kwestia podejścia do zapisu miar kuchennych) i opracowuje strategię przetłumaczenia przepisu. Nauczyciel zapoznaje studentów z możliwymi strategiami do obrania, a następnie wspólnie wybierają jedną z nich - 5-7 minut.

- Nauczyciel wraz ze studentami zastanawia się nad najbardziej problematycznymi jednostkami leksykalnymi i wspólnie rozważają wybór najodpowiedniejszych ekwiwalentów. Oto niektóre sugerowane słowa

${ }^{4}$ http://kolorowakuchnia.blogspot.com/2012/01/marchew-glazurowana-w-miodzie.html, (dostęp: 27 lipca 2012 r.). 
i wyrażenia do przedyskutowania: honey-glazed (glazurowane miodem, glazurowane w miodzie, w polewie miodowej), cup (szklanka czy filiżanka), orange juice (sok pomarańczowy czy sok z pomarańczy) - 5-7 minut.

- Nauczyciel zapoznaje studentów z metodami manipulowania tekstem, których można użyć w tłumaczeniu przepisów kulinarnych - 5 minut.

- Nauczyciel wspólnie ze studentami dokonuje translacji kolejnych segmentów przepisu kulinarnego (tytuł, wprowadzenie, lista składników, procedura przyrządzenia potrawy), sugerując techniki translatorskie i naprowadzając studentów na podjęcie właściwych decyzji translatorskich. Przy okazji nauczyciel doradza w zakresie wprowadzenia wszelkich możliwych zmian w tekście pod względem redakcyjnym - 20-25 minut.

- Nauczyciel przeprowadza krótką dyskusję ze studentami, dotyczącą tego, jakie problemy napotkali podczas dokonywania tłumaczenia tekstu i jak doszli do ich rozwiązania - 2 minuty.

- Nauczyciel zadaje studentom pracę domową (tłumaczenie przepisu kulinarnego). Oprócz przetłumaczonego tekstu zadaniem studentów jest także przyniesienie na kolejne zajęcia zapisu problemów, które napotkali w trakcie dokonywania translacji i w jaki sposób je rozwiązali. Opisany wyżej plan zajęć przedmiotu translatoryka bazuje na tzw. podejściu procesowym $\mathrm{w}$ dydaktyce przekładu. Jest to rodzaj kształcenia ukierunkowanego na studentów, w którym wykorzystuje się metodologię zorientowaną na rozwiązywanie problemów przy ścisłej współpracy nauczyciela i studentów (Fox 2000: 115). Z pewnością podejście takie zasługuje na głębszą refleksję, zwłaszcza w odniesieniu do współcześnie wykorzystywanych metod nauczania przekładu, głównie zorientowanych na końcowy produkt, czyli tekst docelowy. Wydaje się bowiem, że podejście zorientowane na produkt stało się metodologią dominującą na zajęciach z tłumaczeń pisemnych i ustnych, a nie ulega wątpliwości, że w rozwijaniu kompetencji tłumaczy niezbędne staje się zastosowanie innych technik, z powodzeniem stosowanych w zagranicznych ośrodkach zajmujących się przekładem i jego dydaktyką.

Reasumując, tłumaczenie przepisów kulinarnych powinno zostać włączone do sylabusów z przedmiotów translatoryka czy tłumaczenie pisemne tekstów użytkowych, gdyż są to teksty, na które panuje obecnie dość duże zapotrzebowanie. Na współczesnym rynku tłumaczeniowym (biorąc pod uwagę szczególnie wydawnictwa) potrzebni są zatem wykwalifikowani tłumacze, mający wiedzę i doświadczenie w przekładzie omawianego w niniejszym artykule rodzaju tekstu. Przepisy kulinarne powinny znaleźć się w pro- 
gramie nauczania przedmiotów translatorycznych także $\mathrm{z}$ tego względu, że choć pozornie są to teksty dość proste, to jednak stwarzają wiele problemów natury translacyjnej, które z kolei nierzadko prowadzą do wystąpienia poważnych błędów tłumaczeniowych, wpływających na recepcję gotowego produktu tłumaczeniowego. Przyczyną tych trudności niejednokrotnie jest fakt, że przepisy kulinarne są tekstami pełniącymi wiele funkcji i niejednolitymi pod względem stylistycznym. Nie ulega wątpliwości, że omówienie tego typu problemów i potencjalnych błędów jest wręcz niezbędne w kształceniu przyszłych tłumaczy.

Przekładu przepisów kulinarnych powinno się uczyć z wykorzystaniem podejścia zorientowanego na proces, które wydaje się przynosić znacznie więcej korzyści niż podejście zorientowane na finalny produkt tłumaczeniowy, skupiające się w przeważającej mierze na analizie już popełnionych błędów. Argumentować to można przede wszystkim tym, że dzięki pierwszemu podejściu nauczyciel ma możliwość motywowania i zachęcania studentów w większym stopniu do samodzielnego zgłębiania problemów tłumaczeniowych, studenci zaś mogą podzielić się swymi wątpliwościami i trudnościami, które napotkali w procesie przekładu zarówno z nauczycielem, jak i z kolegami z grupy. Rozmowa $\mathrm{w}$ grupie o problemach natury translacyjnej daje studentom większe poczucie pewności siebie, zachęca do dalszej pracy nad własnym warsztatem i pogłębia zainteresowanie tematem tłumaczeń. Działanie takie wpływa na szybsze przyswajanie wiedzy teoretycznej, stosowanie jej zasad w praktyce i nabywanie umiejętności właściwego przeprowadzania procesu tłumaczeniowego. Dzięki współpracy nauczyciela i studentów podczas zajęć z translatoryki rodzi się istotna wymiana myśli i doświadczeń, która może zaowocować w przyszłości.

\section{Literatura}

Belczyk, A., 2007, Poradnik tłumacza, Kraków.

Fox, O., 2000, „The Use of Translation Diaries in a Process-Oriented Translation Teaching Methodology", [w:] Developing translation competence, Ch. Schäffner, B. Adab (red.), Amsterdam-Philadelphia, s. 115-130.

Gile, D., 2009, Basic Concepts and Models for Interpreter and Translator Training, Amsterdam-Philadelphia.

Hervey, S., Higgins, I., Haywood, L., 1995, Thinking Spanish Translation: A Course in Translation Method: Spanish to English, Abingdon-New York. Kozłowska, Z., 2001, „O błędach językowych w tekstach polskich przekładów”, 
[w:] Język rodzimy a język obcy. Komunikacja, przekład dydaktyka, A. Kopczyński, U. Zaliwska-Okrutna (red.), Warszawa, s. 137-147.

Mocarz, M., 2007, „O poprawności przekładu tekstów użytkowych”, [w:] Wspótczesne kierunki analiz przekładowych, M. Piotrowska (red.), Kraków, s. 133-141.

Piotrowska, M., 2011, Learning Translation Learning the Impossible? A Course of translation from English into Polish, Kraków.

Preložniková, S., Toft, C., 2004, „The role of translation studies within the framework of linguistic and literary studies", [w:] Translation in Undergraduate Degree Programmes, K. Malmkjær (red.), Amsterdam-Philadelphia, s. 83-96.

\section{"Delicious translation": how to teach recipes translation from English into Polish}

\section{Summary}

The article focuses on the methodology of teaching recipe translation from English into Polish to beginners in translation studies. The author analyzes the main reasons for incorporating recipes into translation studies syllabus, presents recipes as a specific kind of texts, shows their complexity and various functions, describes most common problems as well as mistakes related to recipes translation, and discusses the example of translation classes plan devoted strictly to translation of recipes.

The author notices the following: 1) Recipes, as a special kind of texts, should be incorporated into translation studies syllabus, because nowadays they are quite popular on the Polish publishing market. In other words, the demand for books and texts related to cooking increases. What is more, recipes are usually quite short, which makes them perfect texts to be used fully during translation classes. 2) Recipes, although seemingly quite simple texts, in fact cause many problems during the translation process; this may give rise to translation mistakes, especially among students who begin courses in translation training. The author, while discussing those problems and mistakes, points to some difficulties in the translation of titles, measurements and culinary units, problems in lexical areas, style, register, and the relation between the author and the reader of the recipe. The author draws attention to the fact that translation trainers should always discuss those problems during the class devoted to recipes' translation. 3) In modern translation didactics translation trainers should pay more attention to the process-oriented than to the product-oriented approach, because the former, as it seems, affects the development of translators' competence more positively than the latter. First of all, owing to the process-oriented approach a translation trainer may motivate students more and encourage them to work individually on their translation. Secondly, students who are taught that way are more responsive and tractable. They focus more on proper translation strategies and techniques than on the errors they make. Thirdly, since the 
process-oriented approach consists mainly in the collaboration between teacher and students and in the formation of the unique translation team, beginning translators acquire theoretical knowledge quicker, use its rules in a practical way, and get to know how to proceed with the translation process properly. Furthermore, they become more confident because of the possibility of sharing translation problems both with the teacher and with other students. The suggested plan of the translation class presented by the author relies on the process-oriented approach towards translation teaching, which leads to the exchange of thoughts and ideas.

\section{(c) $($ ) $\ominus$}

